\title{
Inhibition of In Vivo Constriction of Fetal Ductus Arteriosus by Endothelin Receptor Blockade in Rats
}

\author{
KAZUO MOMMA, TOSHIO NAKANISHI, AND SHINICHIRO IMAMURA \\ Department of Pediatric Cardiology, The Heart Institute of Japan, Tokyo Women's Medical University, \\ Tokyo, Japan
}

\begin{abstract}
The fetal ductus can be constricted by drugs, including cyclooxygenase inhibitors (indomethacin), nitric oxide synthesis antagonists [ $N$-nitro-L-arginine monomethyl ester (L-NAME)], and glucocorticoid hormones (dexamethasone). Constriction of the fetal ductus by endothelin (ET) 1 was reported in an in vitro study. We studied the preventive effect of a dual ET receptor antagonist (bosentan) and a selective ET-A blocker (CI-1020) on pharmacologic fetal ductal constriction in rats. Near-term pregnant Wistar rats at $\mathrm{d} 21$ and preterm rats at $\mathrm{d} 19$ were used. The fetal ductus was constricted by four medications: orogastric administration of indomethacin $(10 \mathrm{mg} / \mathrm{kg})$ on fetal $\mathrm{d} 21$, orogastric indomethacin $1 \mathrm{mg} / \mathrm{kg}$ combined with muscular injection of L-NAME $(10 \mathrm{mg} / \mathrm{kg})$ on fetal $\mathrm{d} 21$, and muscular injection of L-NAME or dexamethasone $(1 \mathrm{mg} / \mathrm{kg})$ on fetal d 19. Bosentan $(0.1,1,10$, or $100 \mathrm{mg} / \mathrm{kg})$ was injected intraperitoneally either simultaneously with indomethacin, L-NAME, or dexamethasone, or $4 \mathrm{~h}$ after administration of $10 \mathrm{mg} / \mathrm{kg}$ indomethacin. CI-1020 $(0.01,0.1,1$, or $10 \mathrm{mg} / \mathrm{kg})$ was injected intraperitoneally simultaneously with indomethacin. After maternal atlas dislocation,
\end{abstract}

\section{ABSTRACT}

cesarean section, fetal whole-body freezing, and cutting on the freezing microtome, measurements were made of the inner diameters of the ductus, main pulmonary artery, and ascending aorta. Bosentan blocked fetal ductal constriction by indomethacin, indomethacin plus L-NAME in the near-term rats, and constriction by L-NAME and dexamethasone in the preterm rats dose dependently. Fetal ductal constriction was nearly completely blocked by simultaneously administered $100 \mathrm{mg} / \mathrm{kg}$ of bosentan or $10 \mathrm{mg} / \mathrm{kg}$ of CI-1020. Dual ET receptor antagonist (bosentan) and selective ET-A blocker (CI-1020) prevent constriction of the fetal ductus arteriosus induced by ductus-constricting agents in rats, indicating that ET and ET-A receptors are essential in fetal ductal constriction. (Pediatr Res 53: 479-485, 2003)

Abbreviations
DA, ductus arteriosus
ET, endothelin
NO, nitric oxide
L-NAME, $N$-nitro-L-arginine monomethyl ester

The DA is widely patent in the fetus, and constricts soon after birth (1). Mechanisms of fetal patency and neonatal constriction of the DA are controversial (2-4). Low $\mathrm{PO}_{2}$ and prostaglandins dilate the fetal DA (2-4). Momma and Toyono (5) showed that NO is a major dilator of the ductus in the preterm fetus. Nakanishi et al. (6) showed increased intracellular calcium of the ductal smooth muscle when constricted by increased oxygen. Coceani and Kelsey (7) suggested a specific role of ET as a mediator of fetal ductal constriction. Their recent study has shown that deletion of the ET-A receptor suppresses oxygen-induced constriction but not postnatal closure of the DA (8). Among four ET, including

Received December 18, 2001; accepted April 16, 2002.

Correspondence: Kazuo Momma, M.D., Department of Pediatric Cardiology, Tokyo Women's Medical University, Kawadacho, Shinjukuku, Tokyo 162-8666, Japan; e-mail: prmomma@nora.hij.twmu.ac.jp

Bosentan was kindly supplied by Dr. Martine Clozel, Actelion Ltd., Allschwil, Switzerland. CI-1020 (PD156707) was kindly supplied by Dr. D.W. Owens, Pfizer Global Research and Development, Ann Arbor Laboratories, Pfizer Inc, Ann Arbor, MI, U.S.A. Supported by a grant in aid from the Ministry of Education, Science, and Culture of Japan and by the Japanese Promotion Society for Cardiovascular Disease.

DOI: 10.1203/01.PDR.0000049516.70216.2E
ET-1, ET-2, ET-3, and ET-4, ET-1 is produced in the vascular endothelium, and induces transient vasodilatation through the ET-B receptor and prolonged vasoconstriction by binding to the ET-A receptor of vascular smooth muscle cells $(9,10)$. Recently, potent mixed and selective ET-A and ET-B blockers have been developed $(9,10)$, including bosentan (mixed blocker) $(11,12)$ and CI 1020 (ET-A blocker) (13-15). The present study was done to prove the role of endogenous ET in fetal ductal constriction in an in vivo study. Three categories of medication can constrict the fetal DA in rats, and are used to induce fetal ductal constriction in this study. These include cyclooxygenase inhibitors such as indomethacin (16), inhibitors of NO synthase such as L-NAME (5), and glucocorticoid hormones such as dexamethasone (17). Combined administration of indomethacin and L-NAME induces strong fetal ductal constriction (5), and this combination was also used in this study.

\section{MATERIALS AND METHODS}

Animals. Virgin Wistar rats (pregnancy period $21.5 \mathrm{~d}$ ) were mated overnight from 1700 to $0900 \mathrm{~h}$; the presence of sperm in 
vaginal smears indicated d 0 of pregnancy. Rats were housed in an environmentally controlled room, acclimatized to a $12 \mathrm{~h}$ light-dark cycle, and maintained on commercial solid food and tap water ad libitum. Treatment conformed to the guiding principles of the American Physiologic Society. The experiment was approved by the Ethical Committee of Animal Experiments of the Institute. Experiments were done either on fetal d 21 (near-term rats) or on fetal d 19 (preterm rats).

Ductus-constricting drugs. Administration of $10 \mathrm{mg} / \mathrm{kg}$ of indomethacin to near-term rats induces severe ductal constric-

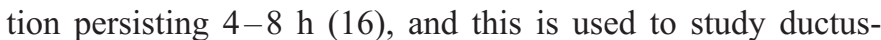
relaxing effects of bosentan. Indomethacin $(1 \mathrm{mg} / \mathrm{kg})$ combined with L-NAME, a NO inhibitor $(10 \mathrm{mg} / \mathrm{kg})(5)$, induces severe ductal constriction in the near-term rats, and this combination was also used. Administration of $10 \mathrm{mg} / \mathrm{kg}$ L-NAME to preterm rats causes severe ductal constriction, and was used in other fetuses. Glucocorticoid hormone constricts the fetal DA, mildly in the near-term fetus and moderately in the preterm fetus (17), so dexamethasone $(1 \mathrm{mg} / \mathrm{kg})$ was also used to constrict the fetal ductus of preterm rats in this study.

ET receptor antagonists. We used bosentan (Ro 47-0203, Actelion Ltd., Basel, Switzerland) to block ET receptors (ET-A and ET-B). Bosentan is a dual ET receptor blocker, and is effective in blocking ET-A and ET-B after oral and intravascular administration $(11,12)$. Effects persist more than $4 \mathrm{~h}(11$, 12). We used CI-1020 (Pfizer, Ann Arbor, MI, U.S.A.) to block ET-A receptor. CI-1020 is a selective ET-A receptor blocker, and effective in blocking ET-A after oral administration (13-15).

Drug administration. Indomethacin (Sumitomo Chemical Co., Osaka, Japan), 1 or $10 \mathrm{mg} / \mathrm{kg}$, was administered to the pregnant rat through an orogastric tube in a suspension with 1 $\mathrm{mL}$ water containing $5 \%$ arabic gum at $0900 \mathrm{~h}$ on $\mathrm{d} 21$ of pregnancy.

L-NAME (Sigma Chemical, St. Louis, MO, U.S.A.), 10 $\mathrm{mg} / \mathrm{kg}$, was dissolved in $1 \mathrm{~mL}$ of physiologic saline and injected intramuscularly into the dorsum of the pregnant rat at 0900 on d 21 of pregnancy. Bosentan $(11,12), 0.1,1,10$, or $100 \mathrm{mg} / \mathrm{kg}$, was dissolved in $1 \mathrm{~mL}$ of DMSO and injected intraperitoneally at $0900 \mathrm{~h}$. Dexamethasone sodium phosphate ( $2 \mathrm{mg}$ in $0.5 \mathrm{~mL}$, Nippon Merck-Banyu, Tokyo, Japan) was injected in a dose of $1 \mathrm{mg} / \mathrm{kg}$ into the dorsum of the pregnant rat at 0900 on d 19 of pregnancy.

Measurements. To study in situ morphology of the fetal DA, a rapid whole-body freezing method was used as described in earlier studies (17-19). Briefly, fetuses were delivered by cesarean section with atlas dislocation of the mother rats, and frozen immediately in acetone cooled to $-80^{\circ} \mathrm{C}$ by dry ice. Body weight of the frozen fetus was measured. Seven or 8 fetuses were studied in each litter. The frozen thorax was cut on a freezing microtome (Komatsu Solidate Co. Ltd., Tokyo, Japan) in the frontal plane, and the inner diameters of the ascending aorta, main pulmonary artery and DA were measured every $100 \mu \mathrm{m}$ in $10-15$ planes with a microscope (Nikon Binocular Stereoscopic Microscope, Nihon Kogaku Co., Tokyo, Japan) and a micrometer (Nikon Ocular Micrometer, Nihon Kogaku Co.) (Fig. 1). Constriction of the fetal ductus was not uniform, but most severe at the aortic end (19) (Fig. 2).

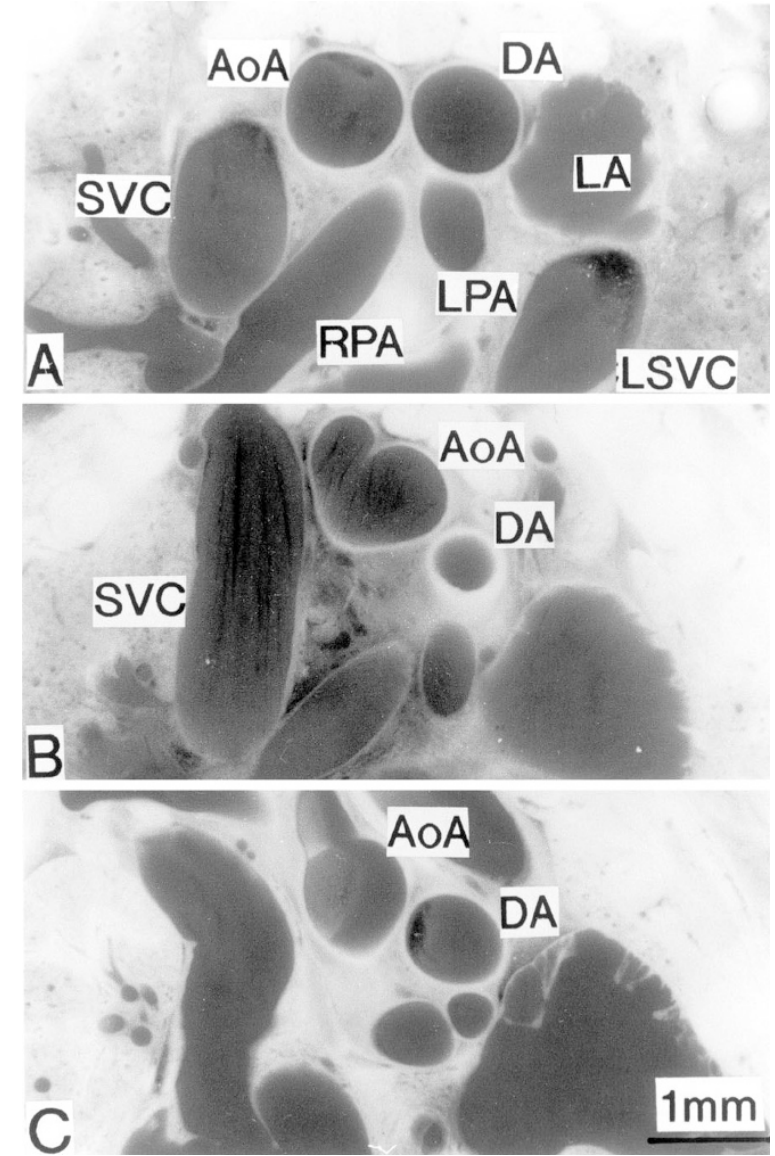

Figure 1. Frontal sections of the near-term DA in the control fetus $(A)$; in the fetus $4 \mathrm{~h}$ after administration of indomethacin $(10 \mathrm{mg} / \mathrm{kg})(B)$; and in the fetus $4 \mathrm{~h}$ after administration of indomethacin $(10 \mathrm{mg} / \mathrm{kg})$ and bosentan $(100 \mathrm{mg} / \mathrm{kg})$ $(C)$. The ductus is widely open in the control fetus, and constricted with indomethacin $(B)$. The ductal constriction with indomethacin is attenuated by bosentan in $C$. AoA, aortic arch; $L A$, left atrium; $L P A$, left pulmonary artery; $L S V C$, left superior vena cava; $R P A$, right pulmonary artery; $S V C$, superior vena cava.

The narrowest ductal diameter was used as the indicator of constriction.

Protocol. The following studies were done using one or two pregnant rats for each drug combination, time and dose. Eight fetuses were studied from each litter. More rats were studied if measurements in fetuses showed large variations. The effects of mixed blocker (bosentan) were studied in the following six studies:

1. The time course of vasodilating effects of bosentan was studied after administration of bosentan $(10 \mathrm{mg} / \mathrm{kg})$ to nearterm rats, and measured 1,4 , and $8 \mathrm{~h}$ later. The effects of an additional larger dose $(100 \mathrm{mg} / \mathrm{kg})$ of bosentan at $4 \mathrm{~h}$ were also studied.

2. The time course of effect of bosentan $(10 \mathrm{mg} / \mathrm{kg})$ administered simultaneously with indomethacin $(10 \mathrm{mg} / \mathrm{kg})$ to nearterm rats was studied at 1,4 , and $8 \mathrm{~h}$ after administration of these drugs. As a control, the time course of ductusconstricting effect of indomethacin $(10 \mathrm{mg} / \mathrm{kg})$ was studied at 1,4 , and $8 \mathrm{~h}$ after administration to near-term rats.

3. The dose-response curve of bosentan $(0,0.1,1,10,100$ $\mathrm{mg} / \mathrm{kg})$ administered simultaneously with indomethacin (10 


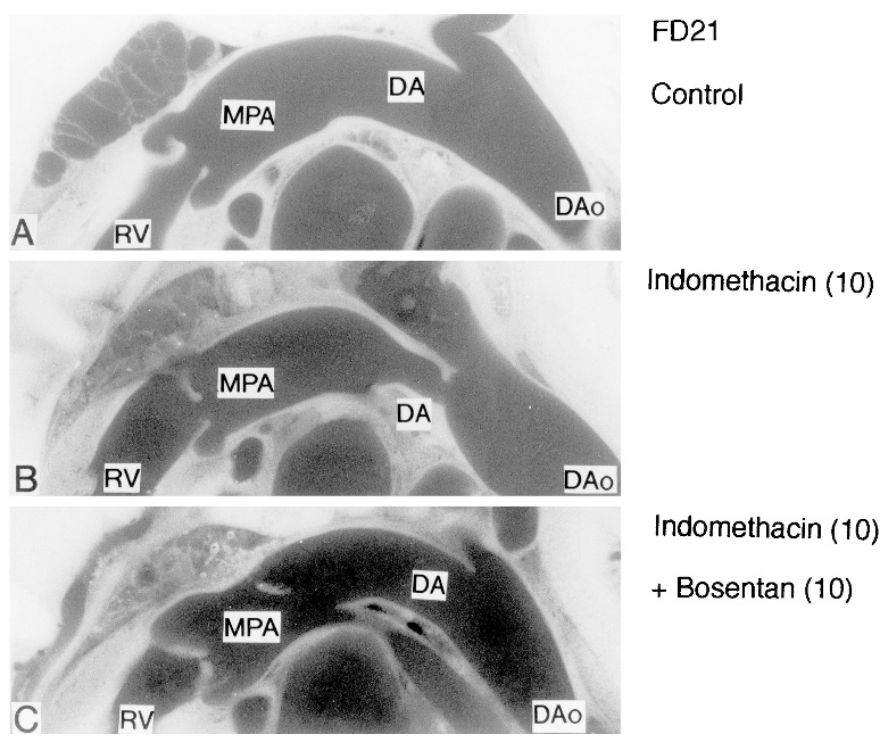

Figure 2. Sagittal sections of the fetal DA in near-term rats. The ductus is widely open in the control $(A)$. It is constricted $4 \mathrm{~h}$ after administration of indomethacin $(10 \mathrm{mg} / \mathrm{kg})(B)$. Ductal constriction is prevented at $4 \mathrm{~h}$ after combined administration of indomethacin $(10 \mathrm{mg} / \mathrm{kg})$ and bosentan $(10 \mathrm{mg} / \mathrm{kg})$ (C). $D A o$, descending aorta; $M P A$, main pulmonary artery; $R V$, right ventricle. Others are the same as in Figure 1.

$\mathrm{mg} / \mathrm{kg}$ ) to near-term rats was studied at $4 \mathrm{~h}$ after administration.

4. To study the dilating effect of bosentan to the already constricted ductus, the dose-response curve of bosentan $(0.1,1$, $10,100 \mathrm{mg} / \mathrm{kg}$ ) administered $4 \mathrm{~h}$ after administration of indomethacin $(10 \mathrm{mg} / \mathrm{kg})$ to near-term rats was studied for an additional $4 \mathrm{~h}$ ( $8 \mathrm{~h}$ after administration of indomethacin).

5. To study the dilating effect of bosentan on the preterm ductus, the dose-response curve of bosentan $(0,0.1,1,10,100$ $\mathrm{mg} / \mathrm{kg}$ ) administered simultaneously with dexamethasone (1 $\mathrm{mg} / \mathrm{kg}$ ) to preterm rats was studied $4 \mathrm{~h}$ after administration.

6. To study the dilating effect of bosentan on the preterm ductus, the dose-response curve of bosentan $(0,0.1,1,10,100$ $\mathrm{mg} / \mathrm{kg})$ administered simultaneously with L-NAME $(10 \mathrm{mg} / \mathrm{kg})$ to preterm rats was studied $4 \mathrm{~h}$ after administration. The effects of a large dose $(100 \mathrm{mg} / \mathrm{kg})$ of bosentan alone to the preterm ductus were studied after $4 \mathrm{~h}$.

The effects of ET-A blocker (CI-1020) were evaluated in the following four studies:

7. The time course of effect of CI-1020 (10 mg/kg) administered to near-term rats was studied at 1,4 , and 8 hours after its administration.

8. The time course of effect of CI-1020 (10 mg/kg) administered simultaneously with indomethacin $(10 \mathrm{mg} / \mathrm{kg})$ to nearterm rats was studied at 1,4 , and $8 \mathrm{~h}$.

9. The dose-response curve of CI-1020 (0, 0.01, 0.1, 1,10 $\mathrm{mg} / \mathrm{kg}$ ) administered simultaneously with indomethacin (10 $\mathrm{mg} / \mathrm{kg}$ ) to near-term rats was studied at $4 \mathrm{~h}$.

10. The dose-response curve of CI-1020 (0, 0.01, 0.1, 1, 10 $\mathrm{mg} / \mathrm{kg}$ ) administered simultaneously with indomethacin (1 mg/ $\mathrm{kg})$ and L-NAME $(10 \mathrm{mg} / \mathrm{kg})$ to near-term rats was studied at $4 \mathrm{~h}$.

Photographs. The sagittal section of the DA was photographed to demonstrate ductal constriction with a binocular stereoscopic microscope (Wild M400 Photomacroscope, Wild Heerbrugg AG, Heerbrugg, Switzerland) using color film (Reale, Fuji Film Co., Tokyo, Japan) (Fig. 2).

Statistics. The results were expressed as mean \pm SEM. The statistical significance of differences between group means was determined by ANOVA and the Bonferroni method (20). The difference was considered to be significant if the $p$ value was $<0.05$.

\section{RESULTS}

The fetal DA was widely patent and the inner diameter was $0.8 \mathrm{~mm}$ in fetuses without medication (Figs. 1-3, Table 1). After administration of bosentan, the fetal ductus and pulmonary artery dilated significantly (Fig. 3, Table 1).

As shown in Figure 3, bosentan reversed fetal ductal constriction by indomethacin after simultaneous administration, partially at $1 \mathrm{~h}$ and more completely at 4 and $8 \mathrm{~h}$.

As shown in Figure 4, administration of a large dose of indomethacin $(10 \mathrm{mg} / \mathrm{kg})$ to near-term rats constricted the fetal ductus severely, and inner diameter decreased to $0.2 \mathrm{~mm}$ (Fig. 4). Bosentan dose-dependently inhibited fetal ductal constriction induced by a large dose of indomethacin (Fig. 4). Bosentan administered simultaneously with indomethacin inhibited fetal ductal constriction more effectively than later administration, in contrast to when the fetal ductus had been previously constricted by indomethacin (Fig. 4).

Constriction of the preterm DA by dexamethasone or LNAME was inhibited by bosentan dose-dependently (Fig. 5). A larger dose $(100 \mathrm{mg} / \mathrm{kg})$ of bosentan inhibited fetal ductal constriction completely.

The ductus-dilating effects of ET-A blocker CI-1020 are shown in Table 1 and Figure 6 and 7. CI-1020, $10 \mathrm{mg} / \mathrm{kg}$, significantly dilated the DA by $25 \%$, the pulmonary artery by $16 \%$, and the ascending aorta by $13 \%$ (Table 1). CI-1020, 10 $\mathrm{mg} / \mathrm{kg}$, effectively reversed ductal constriction by indomethacin when simultaneously administered (Figs. 6 and 7). Dilating effects were more complete at 4 and $8 \mathrm{~h}$ after administration (Fig. 6). Dose-response curves of simultaneously administered CI-1020 with indomethacin $(10 \mathrm{mg} / \mathrm{kg})$ and indomethacin (1 $\mathrm{mg} / \mathrm{kg})$ plus L-NAME $(10 \mathrm{mg} / \mathrm{kg})$ showed maximum effect at 1 and $10 \mathrm{mg} / \mathrm{kg}$, and ductus diameters were in the range of $0.70-0.78 \mathrm{~mm}$ (Fig. 7). These ductus diameters were close to the diameter before any drug was given $(0.80 \mathrm{~mm})$, but smaller than the diameter after administration of CI-1020 (0.96 mm).

\section{DISCUSSION}

Experimentally, inhibition of cyclooxygenase and NO synthase can constrict the near-term and preterm DA, singly or in combination, indicating the dilating effects of prostaglandins and $\mathrm{NO}(1,5,21)$. The fetal DA is most relaxed in low environmental oxygen tension of around $20 \mathrm{~mm} \mathrm{Hg}$ (1). Clinical mechanism of fetal ductal constriction remain highly controversial.

Coceani and Kelsey (7) presented in vitro evidence that ET-1 is a mediator of fetal and neonatal ductal constriction. In their study, ET-1 is synthesized by the fetal DA and the amount of ET increased slightly in higher-oxygen than in low-oxygen 


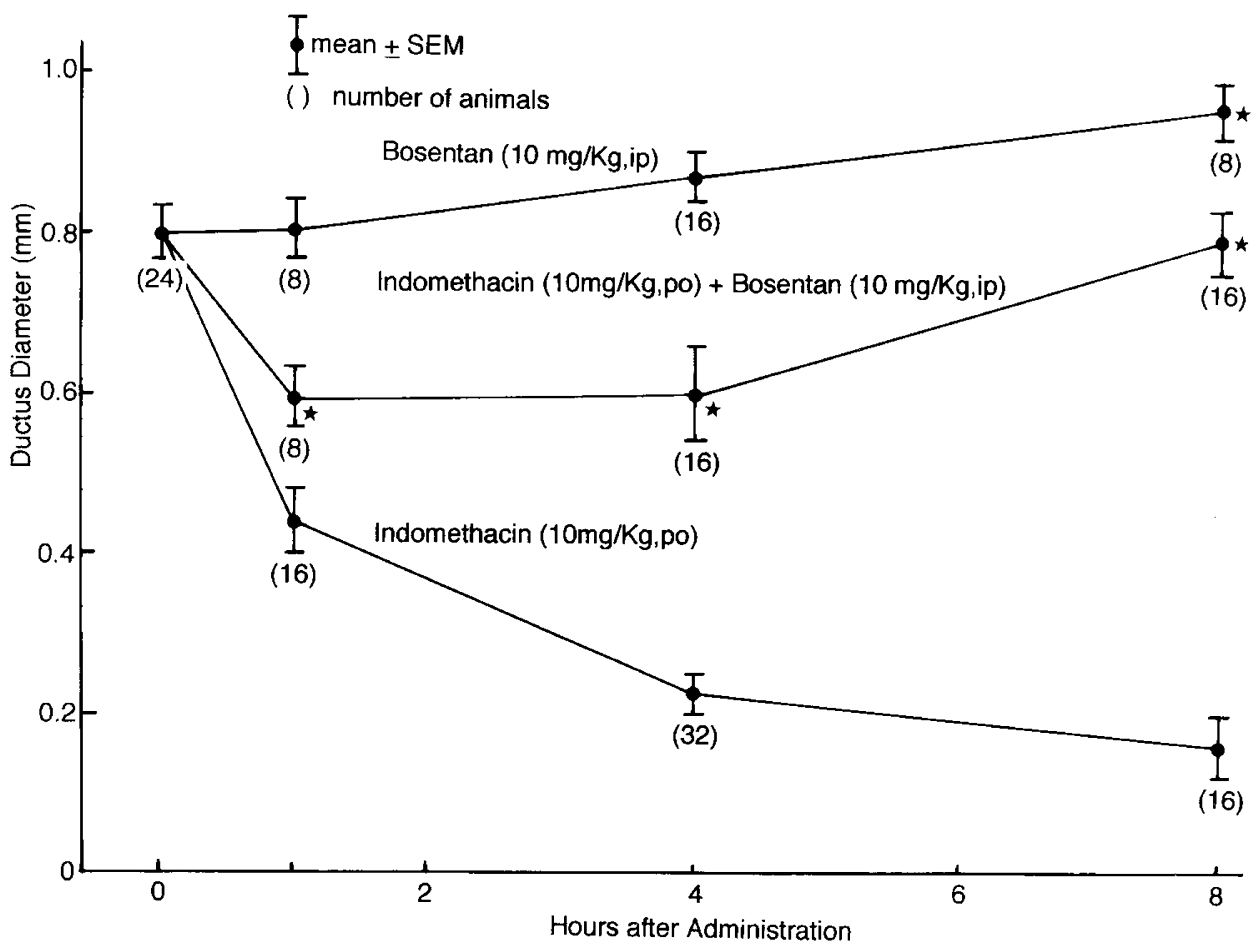

Figure 3. Time course of ductus-dilating effect of bosentan $(10 \mathrm{mg} / \mathrm{kg}$ i.p.), ductus-constricting effect of indomethacin (10 mg/kg p.o.), and effect of simultaneous administration of these two drugs in near-term rats. Bosentan alone dilated the fetal ductus by $20 \%$ at $8 \mathrm{~h}$ after administration. Bosentan inhibited ductal constriction by indomethacin partially at $1 \mathrm{~h}$, but more completely 4 and $8 \mathrm{~h}$. Numbers of studied fetuses are shown in parenthesis. ${ }^{*} p<0.05 v s$ without ET blocker.

Table 1. Dilatation of the DA, ascending aorta, and the main pulmonary artery by endothelin blockers $4 \mathrm{~h}$ after administration in fetal rats

\begin{tabular}{|c|c|c|c|c|c|c|}
\hline Experiment No. and Drug* & $\begin{array}{l}\text { No. of } \\
\text { Fetuses }\end{array}$ & Weight (g) & $\begin{array}{l}\text { Ascending } \\
\text { Aorta }\end{array}$ & $\begin{array}{l}\text { Main Pulmonary } \\
\text { Artery }\end{array}$ & DA & DA/PA Ratio \\
\hline \multicolumn{7}{|l|}{ Near term } \\
\hline 1A:No drug & 24 & $5.8 \pm 0.1$ & $78 \pm 2$ & $79 \pm 2$ & $80 \pm 2$ & $101 \pm 2$ \\
\hline 2A:Indo (10) & 32 & $5.7 \pm 0.2$ & $84 \pm 3 \dagger v s 1 \mathrm{~A}$ & $82 \pm 3$ & $22 \pm 2 \dagger v s 1 \mathrm{~A}$ & $27 \pm 3 \dagger v s 1 \mathrm{~A}$ \\
\hline 2B:Indo (10) + bosentan $(100)$ & 32 & $5.7 \pm 0.1$ & $79 \pm 2$ & $87 \pm 3$ & $74 \pm 5 \dagger v s 2 \mathrm{~A}$ & $85 \pm 5 \dagger v s 2 \mathrm{~A}$ \\
\hline 7A:Cl-1020 (10) & 16 & $5.9 \pm 0.2$ & $89 \pm 3 \dagger v s 1 \mathrm{~A}$ & $92 \pm 4 \dagger v s 1 \mathrm{~A}$ & $96 \pm 3 \dagger v s 1 \mathrm{~A}$ & $104 \pm 3$ \\
\hline $\begin{array}{l}\text { 10C:Indo (1) + L-NAME (10) } \\
\quad+\text { Cl-1020 }\end{array}$ & 16 & $5.8 \pm 0.1$ & $84 \pm 2 \uparrow v s 10 \mathrm{~B}$ & $89 \pm 3 \dagger v s 10 \mathrm{~B}$ & $77 \pm 3 \dagger v s 10 \mathrm{~B}$ & $87 \pm 3 \dagger v s 10 \mathrm{~B}$ \\
\hline \multicolumn{7}{|l|}{ Preterm } \\
\hline 6A:No drug & 16 & $2.5 \pm 0.1$ & $53 \pm 2$ & $58 \pm 2$ & $58 \pm 2$ & $100 \pm 3$ \\
\hline 6B:Bosentan (10) & 12 & $2.7 \pm 0.1$ & $58 \pm 2 \dagger v s 6 \mathrm{~A}$ & $63 \pm 2 \uparrow v s 6 \mathrm{~A}$ & $63 \pm 2 \dagger v s 6 \mathrm{~A}$ & $100 \pm 3$ \\
\hline 6C:L-NAME (10) & 24 & $2.5 \pm 0.1$ & $52 \pm 2$ & $54 \pm 2$ & $20 \pm 2 \dagger v s 6 \mathrm{~A}$ & $41 \pm 3 \dagger v s 6 \mathrm{~A}$ \\
\hline
\end{tabular}

Mean \pm SEM. Arterial diameters were $\times 0.01 \mathrm{~mm}$.

Abbreviations: Cl 1020, a selective blocker of endothelin receptor A; Indo, indomethacin; PA, pulmonary artery.

* Dose in parenthesis in $\mathrm{mg} / \mathrm{kg}$.

$\dagger$ Statistically significant and $p<0.05$.

media. They showed that ET-1 blocker partially relaxed the ductus constricted by high oxygen (7). However, Fineman et al. (22) showed in fetal and neonatal lambs that ET-A blocker (CI 1020) blocked both in vivo and in vitro effects of endogenous ET-1, but had no effect on postnatal ductus constriction nor on in vitro ductus contractile response to oxygen or indo- methacin. In addition, Chatfield et al. (23) could not induce constriction of the fetal DA by ET-1 in an in vitro study. Therefore, the role of ET-1 mediating fetal ductal constriction is controversial.

The present study is the first in vivo study showing the role of ET-1 as a mediator of fetal ductal constriction. Bosentan is 


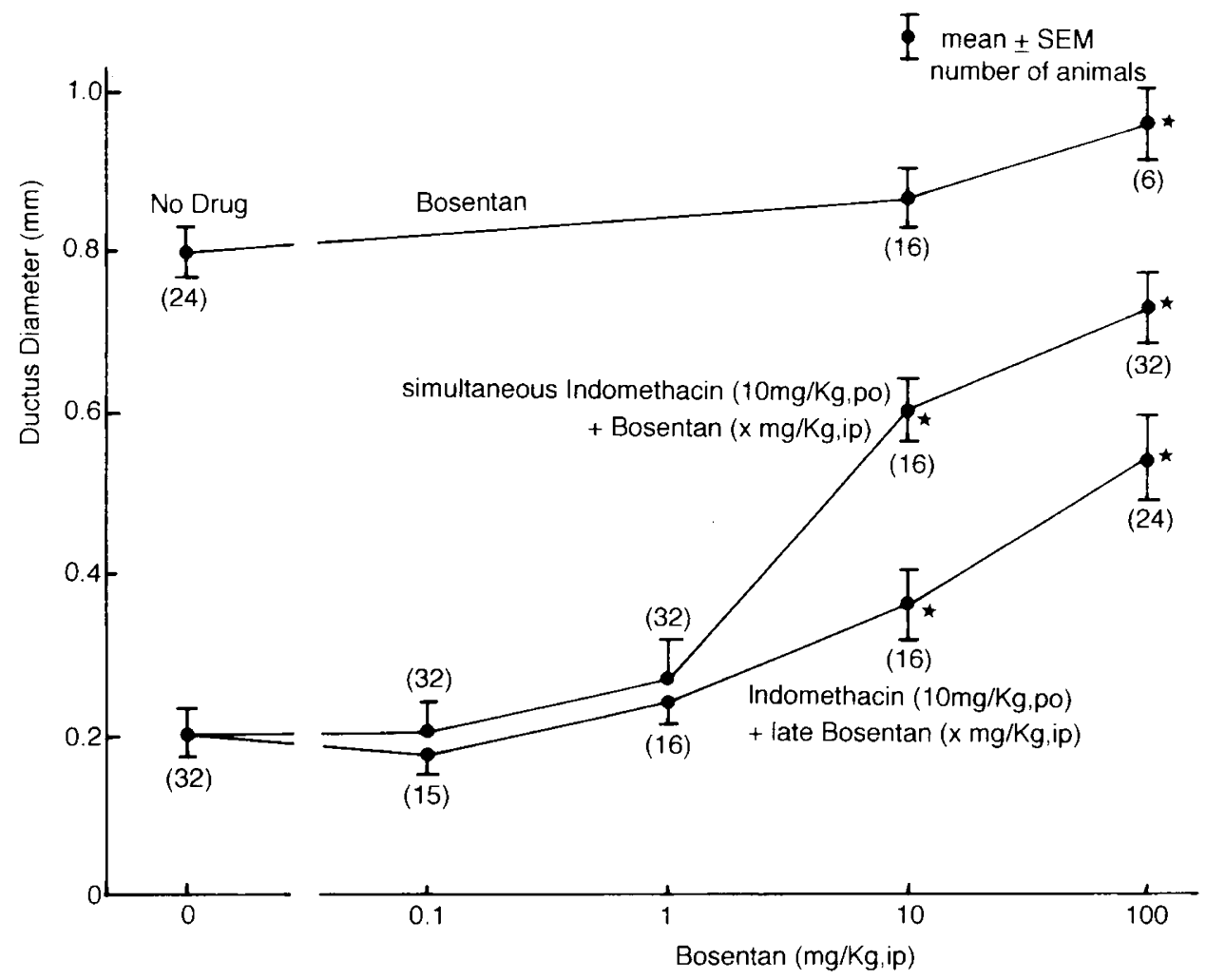

Figure 4. Effects of bosentan in inhibition of near-term ductal constriction by indomethacin. Dose-response curve at $4 \mathrm{~h}$ after administration. Bosentan, 10 and $100 \mathrm{mg} / \mathrm{kg}$, dilated the ductus to $110 \%$ and $120 \%$ significantly. Inhibitory effect of bosentan was more complete with simultaneous administration. With late administration, the reversing effect of bosentan was less complete. Numbers of studied fetuses are shown in parenthesis. ${ }^{*} p<0.05 v s$ without ET blocker.

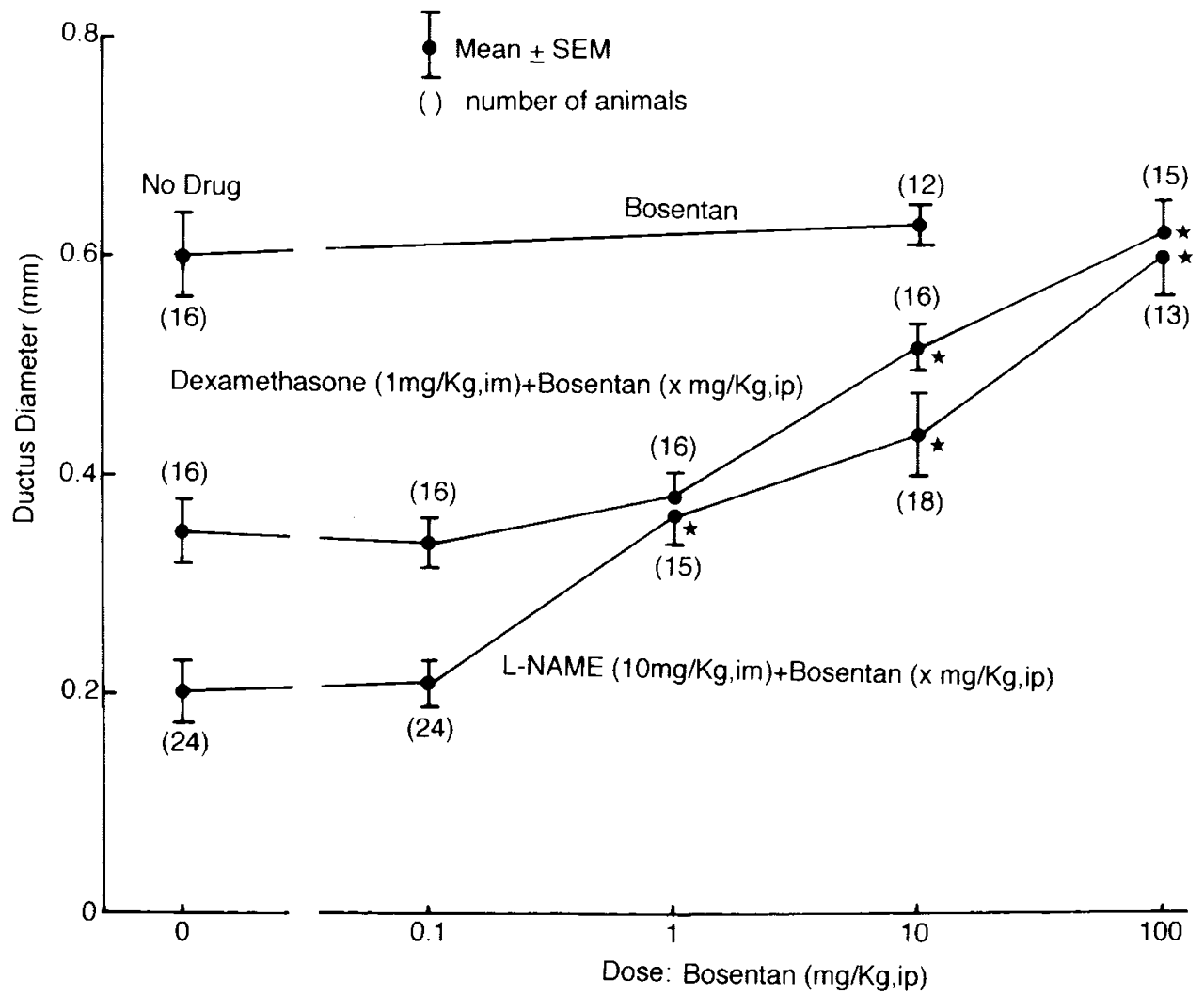

Figure 5. Effects of bosentan in inhibition of preterm ductal constriction by dexamethasone ( $1 \mathrm{mg} / \mathrm{kg}$ i.m.), and L-NAME (10 mg/kg i.m.). Dose-response curves at $4 \mathrm{~h}$ after simultaneous administration. Bosentan, $100 \mathrm{mg} / \mathrm{kg}$, inhibited the ductus-constricting effects of dexamethasone and L-NAME, and dilated the ductus completely. Numbers of studied fetuses are shown in parenthesis. ${ }^{*} p<0.05$ vs without ET blocker. 


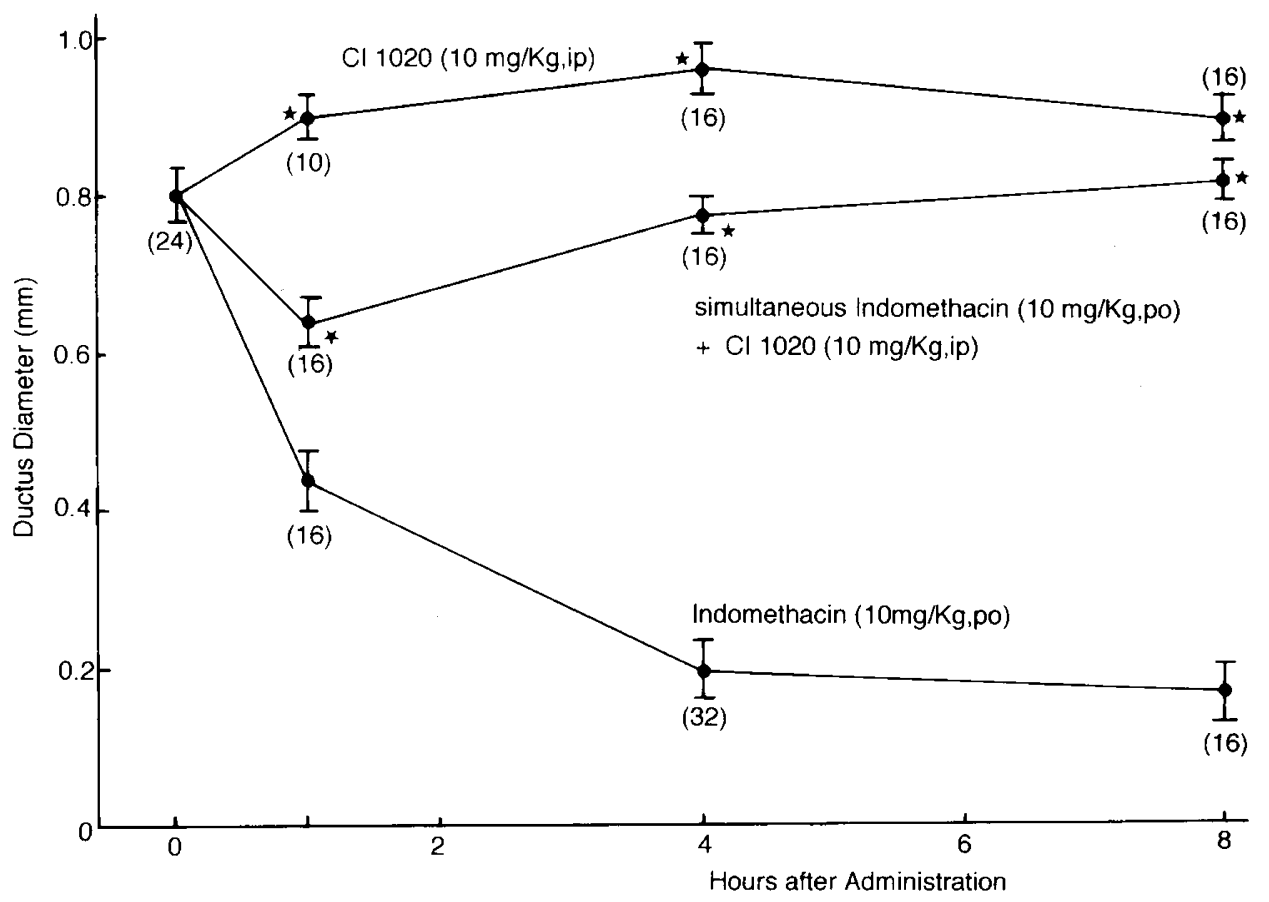

Figure 6. Time course of ductus-dilating effect of ET-A blocker CI-1020 (10 mg/kg i.p.), ductus-constricting effect of indomethacin (10 mg/kg p.o.), and effect of simultaneous administration of these two drugs in near-term rats. CI 1020 dilated the fetal ductus by $20 \%$ at $4 \mathrm{~h}$ after administration. CI-1020 inhibited ductal constriction by indomethacin partially initially, but more completely 4 and $8 \mathrm{~h}$ later. Numbers of studied fetuses are shown in parenthesis. $* p<0.05 v s$ without ET blocker.

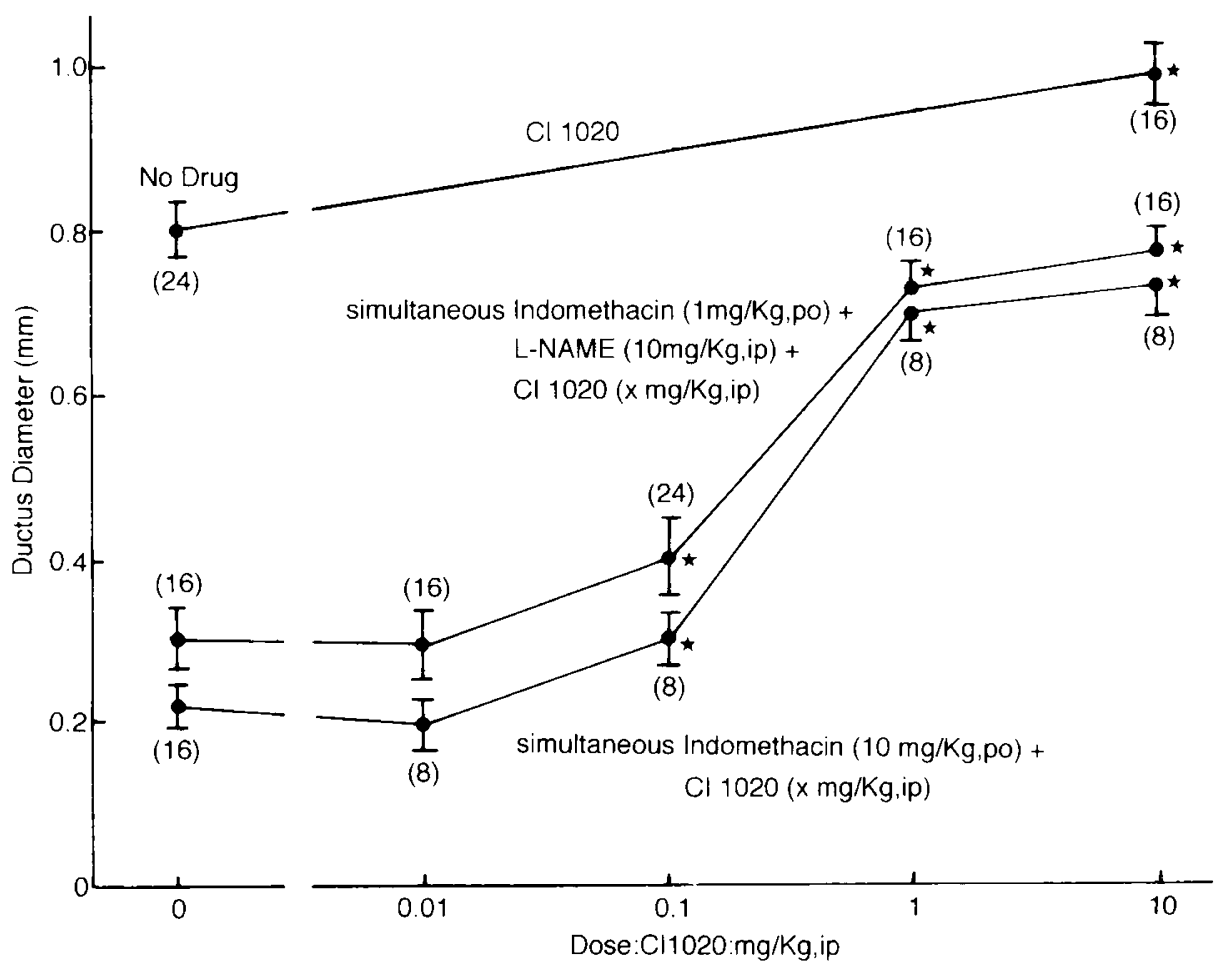

Figure 7. Effects of ET-A blocker CI-1020 on inhibition of ductal constriction by indomethacin ( $1 \mathrm{mg} / \mathrm{kg}$ p.o.) and L-NAME (10 mg/kg i.p.), and indomethacin $(10 \mathrm{mg} / \mathrm{kg}$ p.o. $)$ in near-term fetal rats on fetal d 21. Dose-response curves at $4 \mathrm{~h}$ after simultaneous drug administration. Fetal ductal constriction was effectively reversed with 1 and $10 \mathrm{mg} / \mathrm{kg}$ of CI-1020, and ductal diameter returned to 0.70 and $0.78 \mathrm{~mm}$, respectively. These diameters were not significantly smaller than the diameter with no drug, but smaller than the diameter with CI-1020 $(0.96 \mathrm{~mm})$. Numbers of studied fetuses are shown in parenthesis. * $p<0.05 v s$ without ET blocker.

a potent dual blocker of ET receptors $(11,12)$. It is effective in reducing blood pressure after both intravenous and oral administration $(11,12)$. Although its fetal plasma concentrations were not measured, its transplacental transfer to the fetus is evident by its blocking effects on fetal ductal constriction in our experiments. Maximum blocking effects on ET were ob- 
tained by intravenous injection of $30 \mathrm{mg} / \mathrm{kg}$ of bosentan (11, 12). Transplacental effects in the fetal ductus after intraperitoneal injection in the mother rat was maximum at $100 \mathrm{mg} / \mathrm{kg}$ in this study. This dose is three times larger than the intravenous dose. This difference may be the result of the placental barrier.

In this study, the inhibitory effect of bosentan on fetal ductal constriction was most effective with simultaneous administration with indomethacin, but less effective with late administration. This difference the result of the known firm affinity and prolonged attachment of ET to the receptors (9).

Bosentan is a mixed blocker of ET-A and ET-B receptor, and the ET-A blocking effect is dominant over the ET-B blocking effect (12-15). CI-1020 is a selective blocker of ET-A receptor (12), and its potent blocking effect on fetal ductal constriction in this study shows the ET and ET-A receptor as major mechanisms of pharmacologically induced fetal ductal constriction.

In this in vivo study, the role of endogenous ET in fetal ductal constriction in response to indomethacin, L-NAME, and dexamethasone was evident. Clinically, fetal ductal constriction may be elicited by indomethacin administered to the pregnant woman for tocolysis (24). An ET-1 blocker such as bosentan can be used for inhibition of fetal ductal constriction. A similar clinical situation with fetal ductal constriction is seen with maternally administered glucocorticoid hormone (25).

The mechanism of fetal ductal constriction by maternally administered glucocorticoid hormones is speculative. Glucocorticoids release vascular ET $(26,27)$, and the mechanism of hypertension associated with therapeutic use of glucocorticoids hormones is attributed to this effect. Results of the present study showing blocking effects of bosentan to ductal constriction by dexamethasone are compatible with this ETreleasing effect of glucocorticoids.

Potential secondary effects of ET blockers on maternal and placental hemodynamics and prostaglandin production are not determined in this study. These secondary factors may explain presented results, but remain to be studied in larger animals.

The relevance of the present findings to physiologic closure of the ductus is not clear. It would be more physiologically relevant to test the effectiveness of ETA receptor blockade on ductal potency in the immediate postnatal period when the ductus normally constricts, and this remains to be studied.

Ductal constriction was observed clinically in fetuses with complete transposition of the great arteries who develop pulmonary vascular obstruction and neonatal death (28). An ET blocker such as bosentan may be effective therapeutically to dilate the fetal DA in such a condition. Bosentan is registered for the treatment of pulmonary arterial hypertension (29-31) and can be given safely to children. Whether bosentan is a novel treatment of persistence of the fetal circulation and abnormal closure of the DA (e.g. after antiinflammatory drug administration to the mother) remains to be determined.

\section{REFERENCES}

1. Rudolph AM 2001 Congenital Diseases of the Heart, 2nd Ed. Futura, Armonk, NY, pp 155-196
2. Moor P, Brook MM, Heymann MA 2001 Patent ductus arteriosus. In: Allen HD, Gutgesell HP, Clark EB, Driscoll DJ (eds) Moss Adams Heart Disease in Infants, Children, and Adolescents, 6th Ed. Lippincott Williams \& Wilkins, Philadelphia, pp 652-669

3. Clyman RI 1990 Developmental physiology of the ductus arteriosus. In: Long WA (ed) Fetal \& Neonatal Cardiology, Saunders, Philadelphia,1990. pp 64-75

4. Corbert AJ 1998 Medical manipulation of the ductus arteriosus. In: Garson Jr A Bricker JT, Fisher DJ, Neish SR (eds) The Science and Practice of Pediatric Cardiology, 2nd Ed. Williams \& Wilkins, Baltimore, pp 2489-2513

5. Momma K, Toyono M 1999 The role of nitric oxide (NO) in dilating the fetal ductus arteriosus in rats. Pediatr Res 46:311-315

6. Nakanishi T, Gu H, Hagiwara N, Momma K 1993 Mechanisms of oxygen-induced contraction of ductus arteriosus isolated from fetal rabbit. Circ Res 72:1218-1228

7. Coceani F, Kelsey L 1991 Endothelin-1 release from lamb ductus arteriosus: relevance to postnatal closure of the vessel. Can J Physiol Pharmacol 69:218-221

8. Coceani F, Liu YA, Seidlitz E, Kelsey L, Kuwaki T, Ackerley C, Yanagisawa M 2000 Deletion of the endothelin-A-receptor suppresses oxygen-induced constriction but not post-natal closure of the ductus arteriosus. J Cardiovasc Pharmacol 36(suppl 1):S75S77

9. Miyauchi T, Masaki T 1999 Pathophysiology of endothelin in the cardiovascular system. Ann Rev Physiol 61:391-415

10. Spieker LE, Noll G, Ruschitzka FT, Luscher TF 2001 Endothelin receptor antagonists in congestive heart failure: a new therapeutic principle for the future? J Am Coll Cardiol 37:1493-1505

11. Clozel M, Breu V, Gray GA, Kalina B, Loeffler B-M, Burri K, Cassal J-M, Hirth G, Mueller M, Neidhart W, Ramuz H 1994 Pharmacological characterization of bosentan, a new potent orally active nonpeptide endothelin receptor antagonist. J Pharmacol Exp Ther 270:228-235

12. Roux S, Breu V, Ertel SI, Clozel M 1999 Endothelin antagonism with bosentan: a review of potential application. J Mol Med 77:364-376

13. Reynolds EE, Keiser JA, Haleen SJ, Walker DM, Olszewski B, Schroder RL, Taylor DG, Hwang O, Welch KM, Flynn MA, Thompson DM, Edmunds JJ, Berryman KA, Plummer M, Cheng XM, Patt WC, Doherty AM 1995 Pharmacological characterization of PD 156707, an orally active ETA receptor antagonist. J Pharm Exper Ther 273:1410-1417

14. Uprichard ACG, Metz AL, Hallak H, Haleen SJ 1998 PD-156707: a selective endothelin-A receptor antagonist. Cardiovasc Drug Rev 16:89-104

15. Jones RD, Wanstall JC, Gambino A, Morice AH 1999 The effect of the endothelin ETA receptor antagonist CI-1020 on hypoxic pulmonary vasoconstriction. Eur J Pharmacol 374:367-375

16. Momma K, Takeuchi H 1983 Constriction of fetal ductus arteriosus by nonsteroidal anti-inflammatory drugs. Prostaglandins 26:631-643

17. Momma K, Nishihara S, Ota Y 1981 Constriction of the fetal ductus arteriosus by glucocorticoid hormones. Pediatr Res 15:19-21

18. Momma K, Takao A 1987 In vivo constriction of the ductus arteriosus by nonsteroidal antiinflammatory drugs in near-term and preterm fetal rats. Pediatr Res 22:567-572

19. Momma K, Konishi T, Hagiwara H 1985 Characteristic morphology of the constricted fetal ducts arteriosus following maternal administration of indomethacin. Pediatr Res 19:493-500

20. Wallenstein S, Zucker CL, Fleiss JL 1980 Some statistical methods used in circulation research. Circ Res 47:1-9

21. Seidner SR, Chen YQ, Oprysko PR, Mauray F, Tse MM, Lin E, Koch C, Clyman RI 2001 Combined prostaglandin and nitric oxide inhibition produces anatomic remodeling and closure of the ductus arteriosus in the premature newborn baboon. Pediatr Res 50:365-373

22. Fineman JR, Takahashi Y, Roman C, Clyman RI 1998 Endothelin-receptor blockade does not alter closure of the ductus arteriosus. Am J Physiol 275:H1620-H1626

23. Chatfield BA, McMurphy IF, Hall SL, Abman SH 1991 Hemodynamic effect of endothelin-1 on ovine fetal pulmonary circulation. Am J Physiol 261:R182-R187

24. Huhta JC, Moise KJ, Fisher DJ, Sharif DS, Wasserstrum N, Martin C 1987 Detection and quantification of constriction of the fetal ductus arteriosus by Doppler echocardiography. Circulation 75:406-412

25. Azancot-Benisty A, Benifla JL, Matias A, DeCrepy A, Madelenat P 1995 Constriction of the fetal ductus arteriosus during prenatal betamethasone therapy. Obstet Gynecol $85: 874-876$

26. Kanse SM, Takahashi K, Wallen JB, Ghatei M, Bloom SR 1991 Glucocorticoids induce endothelin release from vascular smooth muscle cells but not endothelial cells. Eur J Pharmacol 199:99-101

27. Morin C, Asselin C, Boudreau F, Provencher PH 1998 Transcriptional regulation of pre-pro-endothelin-1 gene by glucocorticoids in vascular smooth muscle cells. Biochem Biophys Res Commun 244:583-587

28. Maeno YV, Kamenir SA, Sinclair B, Van der Verde M, Smallhorn JF, Hornberger LK 1999 Prenatal features of ductus arteriosus constriction and restrictive foramen ovale in d-transposition of the great arteries. Circulation 99:1209-1214

29. Williamson DJ, Wallman LL, Jones R, Keogh AM, Scroope F, Penny R, Weber C, Macdonald PS 2000 Hemodynamic effects of bosentan, an endothelin receptor antagonist, in patients with pulmonary hypertension. Circulation 102:411-418

30. Channick RN, Simoneau G, Sitbon O, Robbins IM, Frost A, Tapson VF, Badasch DB, Roux S, Rainisio M, Bodin F, Rubin LJ 2001 Effects of the dual endothelin-receptor antagonist bosentan in patients with pulmonary hypertension: a randomized placebocontrolled study. Lancet 358:1119-1123

31. Rubin LJ, Badesch DB, Barst RJ, Galie N, Black CM, Keogh A, Pulido T, Frost A, Roux S, Leconte I, Landsberg M, Simonneau, G 2002 Bosentan therapy for pulmonary arterial hypertension. N Engl J Med 346:896-902 